Nat. Hazards Earth Syst. Sci., 17, 1221-1230, 2017

https://doi.org/10.5194/nhess-17-1221-2017

(C) Author(s) 2017. This work is distributed under

the Creative Commons Attribution 3.0 License.

\title{
Meteorological analysis of flash floods in Artvin (NE Turkey) on 24 August 2015
}

\author{
Hakki Baltaci \\ Turkish State Meteorological Service, Regional Weather Forecast Center, Istanbul, Turkey \\ Correspondence to: Hakki Baltaci (baltacihakki@gmail.com)
}

Received: 27 December 2016 - Discussion started: 17 February 2017

Revised: 12 June 2017 - Accepted: 15 June 2017 - Published: 20 July 2017

\begin{abstract}
On 24 August 2015 intense rainfall episodes generated flash floods and landslides on the eastern Black Sea coast of Turkey. As a consequence of the heavy rainstorm activity over Artvin and its surroundings (NE Turkey), 11 people died and economic losses totaled a million dollars. Over the $6 \mathrm{~h}$ of the event (from 05:00 to 11:00 UTC), total accumulated rainfall amounts of 136, 64, and $109 \mathrm{~mm}$ were measured in the Hopa, Arhavi, and Borçka settlements of Artvin city, respectively. This study comprehensively investigates the meteorological characteristics of those flash floods. In terms of synoptic mechanisms, the cutoff surface low from the summer Asian monsoon settled over the eastern Black Sea. After two days of quasistationary conditions of this cyclone, sea surface temperatures (SSTs) reached $27.5^{\circ} \mathrm{C}\left(1.5^{\circ} \mathrm{C}\right.$ higher than normal $)$ and low-level moisture convergence developed. In addition, transfer of moisture by warm northerly flows from the Black Sea and relatively cool southerly flows from the land coasts of the Artvin district exacerbated the unstable conditions and thus played a significant role in the development of deep convective cells. Severe rainstorms as well as the slope instability of the region triggered landslides and worsened flood damages in the Artvin area. This study supports conventional weather analysis, satellite images, and forecast model output to alert forecasters to the potential for heavy rainfall.
\end{abstract}

\section{Introduction}

The interaction between mesoscale convective systems (MCS) in the warm Mediterranean Sea and sudden orographic lifting in the coastal regions produces severe precipitation over the Mediterranean countries (Rebora et al.,
2012). These severe precipitation events generally generate flash floods and cause serious damages and economic losses. For example, just a single flash flood caused EUR 1.2 billion damages in the Gard region of France in 2002 (Huet et al., 2003), EUR 300 million damages in the Pinios (Greece) flash flood during 1994 (Gaume et al., 2008), EUR 65 million economic losses in the Magorala (Spain) flash flood in 2000 (Llasat et al., 2001), and EUR 4.6 million in the 2007 Mastroguglielmo (Italy) flash-flood event (Aronica et al., 2008). Due to its huge social and economic impacts, it is necessary to improve our current understanding of the spatiotemporal dynamics of flash floods in order to improve forecasts and land-use planning. For this reason, several studies have analyzed the meteorological (e.g., Milelli et al., 2006; Fragoso et al., 2012), hydrological (e.g., Silvestro et al., 2012), or hydrometeorological (e.g., Delrieu et al., 2005; Borga et al., 2007) characteristics of floods at a particular area and time.

Depending on the catchments characteristics, two types of flood mainly occur in Turkey. In the first type, river basins respond rapidly to intense rainfall because of steep slopes, impermeable surfaces, saturated soils, or because of anthropogenic forcing to the natural drainage. As a consequence of this type flooding, large areas are affected, and economic losses are considerable (e.g., the overflow of the Meriç River in NW Turkey). The second type, which is more common, is when flash floods are suddenly triggered by severe rainstorms in certain areas (e.g., coastal regions of the country). In this context, numerous studies have investigated the meteorological role in the occurrence of flash floods in different parts of Turkey. Kömüşçü et al. (1998) analyzed the meteorological and terrain features of the flash flood that occurred on 3 and 4 November 1995 on the Aegean coast, when 61 people died in İzmir (western Turkey). They emphasized 


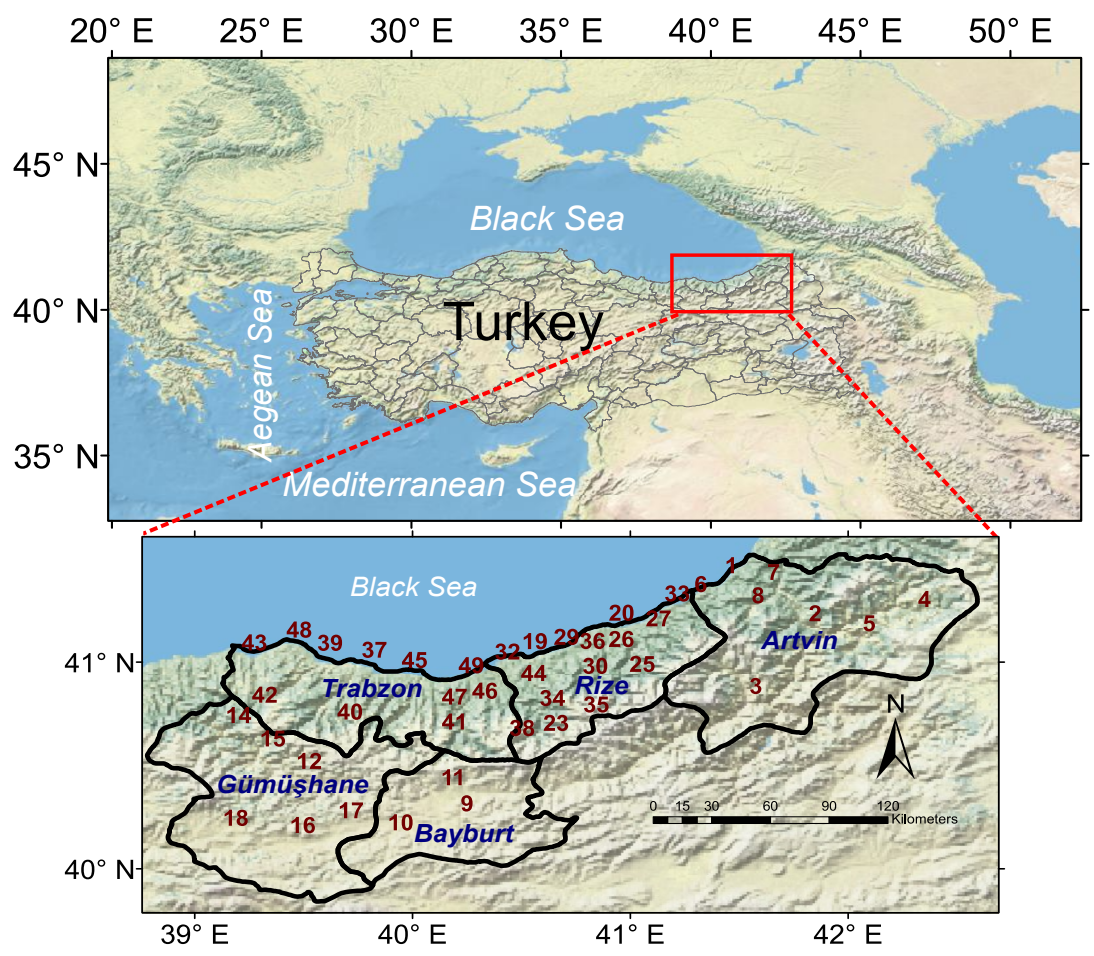

Figure 1. The eastern Black Sea region including city names and borders and 49 automated meteorological stations (descriptions of the station numbers are explained in Table 1). The outset shows location of the region in Turkey.

that low-level advection, positive vorticity, and strong upperlevel divergence together with a squall line oriented NE-SW over the Aegean Sea exacerbated the storm. Subsequently, Kotroni et al. (2006) investigated the storm activity that occurred on 5 December 2002 in Antalya, a coastal city located on the Mediterranean Sea. They found that warm and moist air masses driven by a low-level jet as well as orographic barriers caused more than $230 \mathrm{~mm}$ of $24 \mathrm{~h}$ accumulated precipitation during the event. Later, Kömüşcü and Çelik (2013) investigated the hydrometeorological role of floods that occurred during 7-10 September 2010 in the Marmara Region. They concluded that cold air in the upper atmosphere, slow-moving quasistationary trough and continuous moisture transfer from the warm Aegean Sea to the surface low were the main mechanisms that led to intense storms.

In contrast to the previous studies mentioned above, many severe precipitation events frequently occur and generally conclude with flash floods and triggered landslides in the eastern Black Sea (EBS) region of Turkey (Fig. 1). The EBS comprises the Black Sea (BS) in the north and the eastern Anatolian Peninsula in the south. The underlying geology of the EBS is generally consists of semi-permeable volcanic rocks which reduce infiltration and enhance runoff production (Üçüncü et al., 1994). The northeastern coastal parts of Turkey, regions located on the windward slopes of the EBS facing the Black Sea, receive more than $2000 \mathrm{~mm}$ of annual precipitation, which makes it the wettest part of the country.
The large mountainous area which extends through the Black Sea and slope instability due to steep gradients as well as intense rainfall result in flash floods and landslides and threaten the settlements in the EBS region. In addition to all these topographical and meteorological factors, commercial development and urbanization of the region (e.g., the cultivation of tea on the sloping terrain instead of deep-rooted trees and illegal land usage) facilitate the flooding. Yüksek et al. (2013) have emphasized that 258 deaths and USD 500000000 economic losses occurred as a result of the 51 big floods in this basin from 1955 to 2005 . They briefly selected and analyzed the hydrometeorological role of nine floods in the region. In one of the latest rainstorm events in the EBS, more than $135 \mathrm{~mm}$ of $24 \mathrm{~h}$ accumulated rainfall in the Artvin surroundings (i.e., 144, 136, and $149 \mathrm{~mm}$ in Hopa, Arhavi and Borçka stations, respectively) caused flash floods and landslides on 24 August 2015, resulting in 11 deaths and a million dollars worth of economic losses (Fig. 2). In spite of the several negative impacts of flooding for the region and country, there are no detailed studies in the literature which investigate the detailed meteorological role in the development of the convective cells for the EBS. Therefore, the aim of this research is focused on this extreme event, with the following main objectives: (a) to provide a detailed spatiotemporal evaluation of rainstorms on 24 August 2015, which triggered the flash floods and landslides. Daily and hourly precipitation measurements of the available meteorological stations were 
Table 1. Description of 49 meteorological stations in the study. Stations marked by stars were used for the climatological approach.

\begin{tabular}{|c|c|c|c|c|c|c|c|}
\hline $\begin{array}{l}\text { Station } \\
\text { No. }\end{array}$ & $\begin{array}{r}\text { Station } \\
\text { code }\end{array}$ & Station name & $\begin{array}{r}\text { Longitude } \\
\left({ }^{\circ} \mathrm{E}\right)\end{array}$ & $\begin{array}{r}\text { Latitude } \\
\left({ }^{\circ} \mathrm{N}\right)\end{array}$ & $\begin{array}{r}\text { Altitude } \\
(\mathrm{m})\end{array}$ & $\begin{array}{l}23 \text { Aug } 2015 \\
\text { precipitation } \\
(00: 00 \mathrm{UTC})\end{array}$ & $\begin{array}{l}24 \text { Aug } 2015 \\
\text { precipitation } \\
\text { (00:00 UTC) }\end{array}$ \\
\hline 1 & 17042 & Hopa* & 41.4330 & 41.4065 & 33 & 55.3 & 144.3 \\
\hline 2 & 17045 & Artvin* & 41.8187 & 41.1752 & 613 & 0 & 1.4 \\
\hline 3 & 18216 & Yusufeli & 41.5464 & 40.8228 & 601 & 0 & 4.4 \\
\hline 4 & 18217 & Savsat & 42.3206 & 41.2433 & 1125 & 0 & 24.4 \\
\hline 5 & 18218 & Ardanuc & 42.0653 & 41.1267 & 577 & 0 & 11.6 \\
\hline 6 & 18554 & Arhavi & 41.2928 & 41.3166 & 290 & 22.4 & 135.5 \\
\hline 7 & 18555 & Borcka & 41.6281 & 41.3750 & 190 & 35.8 & 148.9 \\
\hline 8 & 18556 & Murgul & 41.5564 & 41.2617 & 565 & 0.2 & 42.5 \\
\hline 9 & 17089 & Bayburt* & 40.2207 & 40.2547 & 1584 & 0.4 & 0 \\
\hline 10 & 18219 & Demirozu & 39.8858 & 40.1639 & 1757 & 0 & 0 \\
\hline 11 & 18557 & Aydintepe & 40.1294 & 40.3817 & 1600 & 0.6 & 0 \\
\hline 12 & 17088 & Gumushane* & 39.4653 & 40.4598 & 1216 & 0.1 & 0 \\
\hline 13 & 17696 & Torul (Zigana kayak m) & 39.4037 & 40.6413 & 2050 & 0 & 0 \\
\hline 14 & 18226 & Kurtun & 39.1456 & 40.6825 & 739 & 0 & 1.5 \\
\hline 15 & 18227 & Torul & 39.2989 & 40.5686 & 1009 & 0 & 0 \\
\hline 16 & 18228 & Kelkit & 39.4361 & 40.1506 & 1483 & 0 & 0 \\
\hline 17 & 18564 & Kose & 39.6578 & 40.2217 & 1635 & 0.1 & 0 \\
\hline 18 & 18565 & Siran & 39.1289 & 40.1856 & 1490 & 3.3 & 0 \\
\hline 19 & 17040 & Rize* & 40.5013 & 41.0400 & 3 & 28.3 & 26.2 \\
\hline 20 & 17628 & Pazar* & 40.8993 & 41.1777 & 78 & 35.8 & 49 \\
\hline 21 & 17713 & Camlihemsin (Ayder FI) & 41.1103 & 40.9518 & 1354 & 1.6 & 18.8 \\
\hline 22 & 17741 & Ikizdere (Sivrikaya) & 40.7106 & 40.6711 & 1926 & 0 & 7.8 \\
\hline 23 & 17757 & Ikizdere (Derekoy) & 40.5989 & 40.7258 & 970 & 0.4 & 37.2 \\
\hline 24 & 17761 & Kalkandere & 40.4400 & 40.9278 & 138 & 5.7 & 75.1 \\
\hline 25 & 17765 & Camlihemsin & 40.9942 & 41.0125 & 390 & 2.8 & 32.1 \\
\hline 26 & 17769 & Hemsin & 40.8992 & 41.0503 & 307 & 22.3 & 21.9 \\
\hline 27 & 17772 & Ardesen (Yesiltepe) & 41.0703 & 41.1528 & 573 & 0.4 & 0 \\
\hline 28 & 17775 & Iyidere (Fidanlik) & 40.3319 & 40.9835 & 6 & 21.1 & 29.8 \\
\hline 29 & 17781 & Cayeli (Teias) & 40.7417 & 41.0603 & 54 & 31.9 & 30.9 \\
\hline 30 & 17785 & Cayeli (Kaptanpasa) & 40.7789 & 40.9583 & 483 & 15.2 & 54.1 \\
\hline 31 & 17800 & Guneysu & 40.6083 & 40.9897 & 124 & 31.1 & 58.8 \\
\hline 32 & 18566 & Derepazari & 40.4289 & 40.9897 & 397 & 20.1 & 38 \\
\hline 33 & 18567 & Findikli & 41.1556 & 41.2703 & 190 & 24.7 & 62.3 \\
\hline 34 & 18568 & Rize (Andon) & 40.5825 & 40.8711 & 615 & 12.6 & 88.8 \\
\hline 35 & 18569 & Ikizdere (Cimil) & 40.7828 & 40.7333 & 2020 & 0.5 & 16.3 \\
\hline 36 & 18905 & Cayeli (Bakir) & 40.7669 & 41.0408 & 100 & 32.3 & 56.5 \\
\hline 37 & 17037 & Trabzonbolge* & 39.7649 & 40.9985 & 25 & 2.6 & 17.4 \\
\hline 38 & 17569 & Caykara (Uzungol) & 40.4435 & 40.6193 & 1114 & 1.6 & 11.6 \\
\hline 39 & 17626 & Akcaabat* & 39.5615 & 41.0325 & 3 & 1 & 36.6 \\
\hline 40 & 17714 & Macka (Altindere sume.) & 39.6532 & 40.6985 & 1030 & 0.4 & 1.6 \\
\hline 41 & 18229 & Duzkoy & 40.1339 & 40.7708 & 622 & 0.7 & 8.2 \\
\hline 42 & 18230 & Tonya (Kalincam) & 39.2617 & 40.7803 & 1100 & 0 & 7.1 \\
\hline 43 & 18231 & Besikduzu & 39.2144 & 41.0328 & 374 & 12 & 30.1 \\
\hline 44 & 18232 & Hayrat (Pazaronu) & 40.4961 & 40.8858 & 367 & 17.6 & 43 \\
\hline 45 & 18233 & Arsin & 39.9497 & 40.9486 & 169 & 0 & 14.5 \\
\hline 46 & 18570 & Dernekpazari & 40.2719 & 40.7997 & 721 & 7 & 9.7 \\
\hline 47 & 18571 & Koprubasi (Beskoy) & 40.1339 & 40.7710 & 975 & 14 & 17.3 \\
\hline 48 & 18573 & Carsibasi (Yoroz) & 39.4208 & 41.0950 & 370 & 1.2 & 47.8 \\
\hline 49 & 18574 & Surmene (Denizbilimleri) & 40.2097 & 40.9231 & 5 & 49.5 & 33.8 \\
\hline
\end{tabular}

used to understand temporal and spatial behavior of the rainstorm in the different geographic elevations. (b) We aim to improve our understanding of the meteorological features of this extreme event by focusing on the relevant atmospheric synoptic conditions, satellite and radar images, and physical mechanisms (e.g., sea surface temperature evolution) that favored its development.

\section{Data and methodology}

In order to evaluate the research results, precipitation, sea surface temperature, synoptic, and atmospheric data are included in the study. To compare precipitation observations with weather forecasts, three numerical weather prediction (NWP) model outputs were assessed. 
(a)

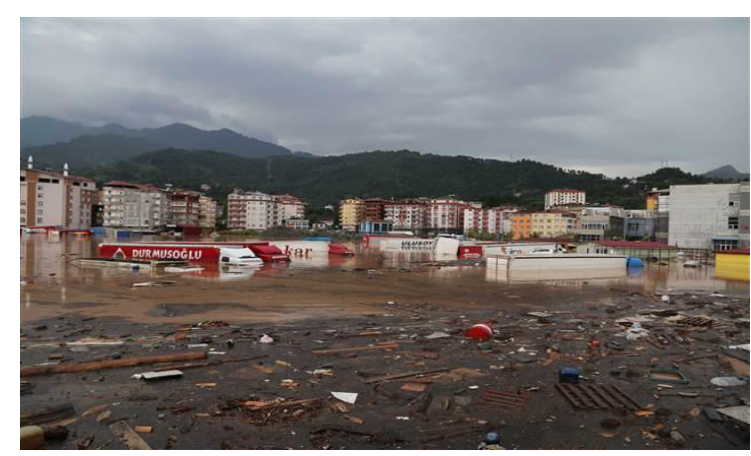

(b)

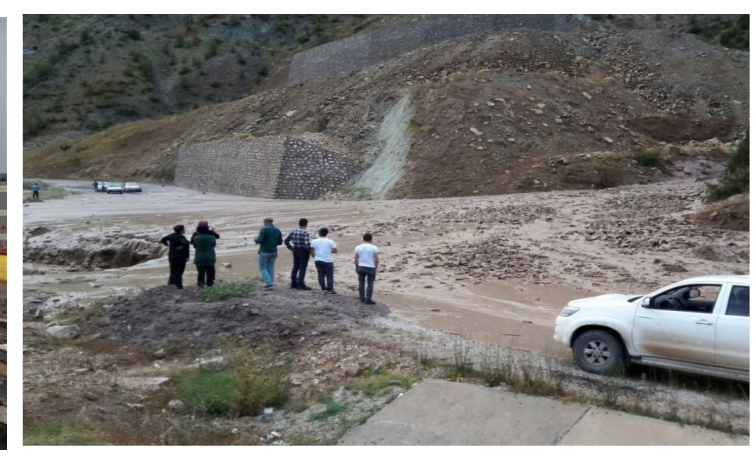

Figure 2. Photos showing the destructive effects of the 24 August 2015 flash floods and landslides: (a) Hopa city center flash flood and (b) landslide in Hopa.

\subsection{Precipitation and sea surface temperature (SST) data}

The eastern Black Sea region is well covered by automated meteorological stations. In addition to the eight long-term stations in the region, 41 new automated meteorological stations have been added since 2013. To present the high spatial resolution and to retrieve a homogeneous data set, hourly and daily precipitation data of 49 stations operated by the Turkish State Meteorological Service (TSMS) were used in the study (Fig. 1). The main characteristics of the stations are described in Table 1.

\subsection{Synoptic and atmospheric data}

The synoptic context of the extreme event of 24 August 2015 as well as atmospheric conditions from the previous day were analyzed with NCEP/NCAR $2.5^{\circ} \times 2.5^{\circ}$ latitude/longitude reanalysis data. To track the intense rainfall episodes, radar PPI (plan position indicator) images, which provided by TSMS, were used. Rainstorm development stages associated with the flash flood were evaluated with Meteosat 10 images.

\subsection{Numerical weather prediction (NWP) model outputs}

Operationally, one global and two regional NWP models are run regularly twice a day (00:00 and 12:00 UTC) for the precipitation forecast by TSMS. In terms of the global NWP, the horizontal grid resolution of ECMWF (European Centre for Medium-Range Weather Forecasts) the IFS (Integrated Forecast System) covers almost $16 \mathrm{~km}$ and uses 91 vertical levels. For the regional weather forecasts, the Alaro meteorological model has been designed to be run at convection-permitting resolutions. The key concept is in the precipitation and cloud scheme called Modular Multiscale Microphysics and Transport (3MT) developed by Gerard and Geleyn (2005), Gerard (2007), and Gerard et al. (2009). In the usage of the Alaro by TSMS where the outer domain has grid spacing of $10 \mathrm{~km}$, the inner domain has almost $5 \mathrm{~km}$ of grid spacing as well as 60 vertical levels.

The mesoscale NWP system of a nonhydrostatic mesoscale model (NMM) core of the Weather Research and Forecasting (WRFg) is developed by the National Oceanic and Atmospheric Administration (NOAA)/National Centers for Environment Prediction (NCEP), WRF-NMM is a fully compressible, non-hydrostatic mesoscale model with a hydrostatic option (Janjic, 2003). The model uses a terrainfollowing hybrid sigma-pressure vertical coordinate. The grid staggering is the Arakawa E-grid. The model uses a forward-backward scheme for horizontally propagating fast waves, an implicit scheme for vertically propagating sound waves, the Adams-Bashforth scheme for horizontal advection, and the Crank-Nicholson scheme for vertical advection. The dynamics conserve a number of first- and second-order quantities including energy and enstrophy. In the study, model has a horizontal grid spacing of $30 \mathrm{~km}$ in its outer computational domain, and the inner domain has a grid spacing of $10 \mathrm{~km}$ together with 46 vertical levels. To compare precipitation forecasts of these models with the observation results, daily precipitation forecasts of the models belonging on the last runtime for 24 August 2015, at 00:00 UTC outputs were assessed.

\section{Results and discussion}

\subsection{Precipitation climate of eastern Black Sea}

The coastal part of the region is restricted by the EBS Mountain chain in the south and the BS in the north (Fig. 1). This mountain chain extends parallel to the Black Sea and has an average altitude of $2000 \mathrm{~m}$. It rises to $3973 \mathrm{~m}$ at its highest point (Eris et al., 2012). Apart from the basic synoptic scale circulations such as continental polar and tropical air masses, the region is also affected by orographic precipitation. Colder air masses are prevented by the Caucasus Mountains (the highest point of Georgia) from the north; therefore, 


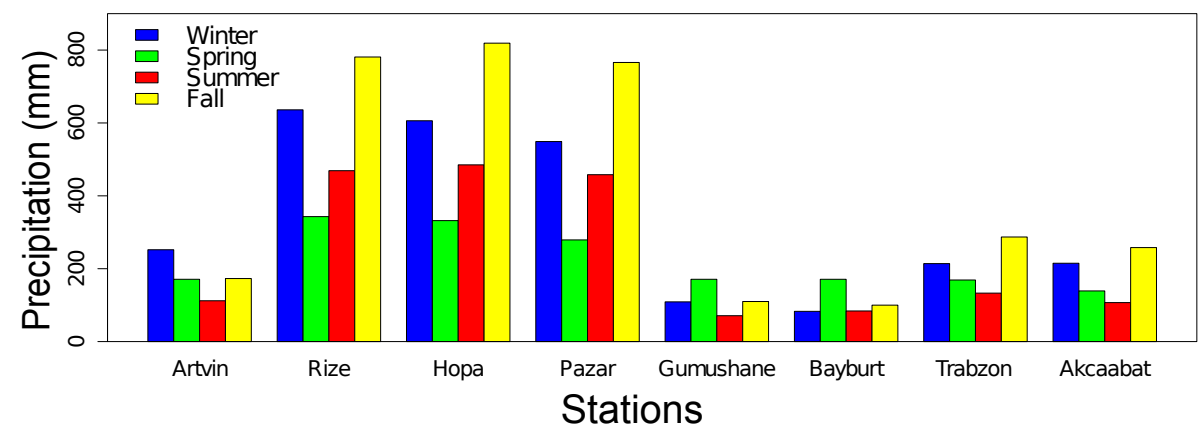

Figure 3. Long-term (1960-2014) mean of the seasonal precipitation amounts related to the eight meteorological stations in the EBS.

more dry climates are seen in the southern part of the region. The rain shadow effect on the lee side of the mountainous area causes a more continental climate in the southern parts of the EBS (Biyik et al., 2010). When compared with the other regions, highest winter and summer precipitation totals are observed in this part of Turkey due to the interactions of synoptic weather patterns and orographic lifting. (Unal et al., 2012). To better visualize the seasonal precipitation variability in the EBS, long-term precipitation data from 1960 to 2014 were extracted from the available eight meteorology stations (stations marked by stars in Table 1 were used for the climatological approach in Fig. 3). Five stations are located in the north of the region. According to the results, mean annual precipitation (MAP) varies from $438 \mathrm{~mm}$ in the south (Bayburt) to $2243 \mathrm{~mm}$ in the north (Hopa). This high spatial precipitation variability generates different land cover terrain. Interestingly, the highest seasonal precipitation amounts in the coastal areas were observed in the fall (SON) months. This can be explained by the significance of MCS, flow directions and SST variations over EBS. In the second wettest season (DJF), highest precipitation records were observed at Hopa, Rize, and Pazar stations with the values 606, 636 , and $550 \mathrm{~mm}$, respectively.

\subsection{Spatiotemporal variability of rainfall episodes}

In Fig. 4a, spatial distribution of daily precipitation totals for 24 August 2015 was extracted from 49 meteorological stations. It can be seen that three main cores of precipitation are measured at the Arhavi, Hopa, and Borçka stations with the values of 135, 144, and $149 \mathrm{~mm}$, respectively. In Hopa, $27 \%$ of the long-term mean of summer rainfalls was recorded on this day. As a consequence of the intense daily rainfall episodes, these three surrounding areas of the Artvin district were the most influenced by flash floods and landslides (i.e., Hopa, Arhavi, and Borçka). Among these stations, Hopa (33 m altitude, no. 1 in Fig. 1b) is at the lowest altitude and is located in the northern coastal part of Artvin city. Borçka station is shown with an altitude of $190 \mathrm{~m}$ (the second lowest altitude in Artvin, no. 7 in Fig. 1b). Another coastal station, Arhavi (290 m altitude, no. 6 in Fig. 1b), is located in the

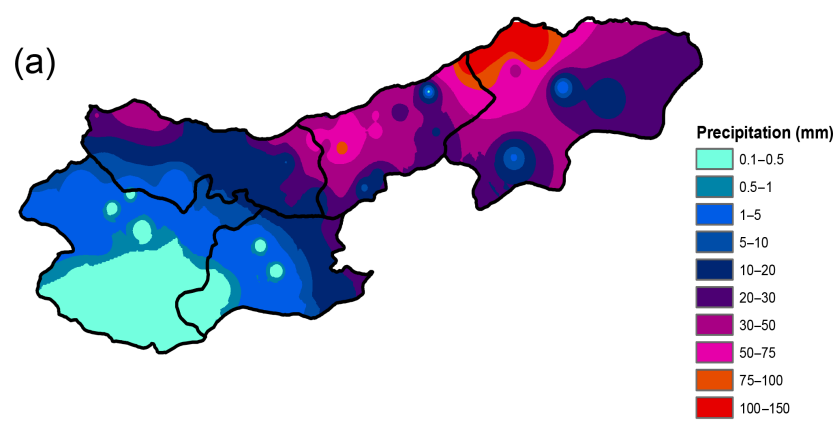

(b)

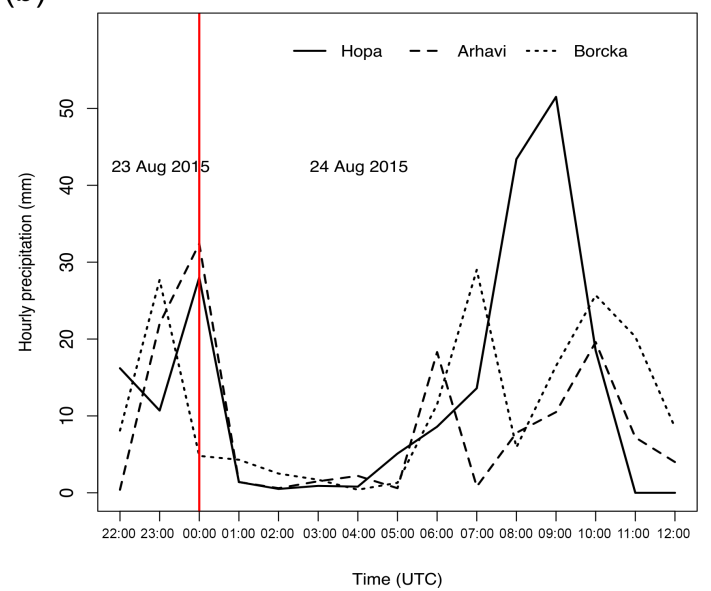

Figure 4. (a) Total daily precipitation in the eastern Black Sea (00:00-24:00 UTC), 24 August 2015. The map is based on data from the same meteorological stations represented in Fig. 1 (station names are listed in Table 1). (b) Hourly evolution of the $24 \mathrm{Au}-$ gust 2015 rainstorm in Artvin at three selected stations representing flash-flood regions.

northwest and has the third lowest altitude among all Artvin stations. Temporal precipitation distribution of these selected stations was extracted as shown in Fig. 4b. Rainstorms started in the evening (22:00 UTC) of 23 August 2015 and ended at midday on the following day. Hourly observations at the three stations showed the torrential rains increased from 27 to $32 \mathrm{~mm}$ between 22:00 and 24:00 UTC on 23 August. There- 

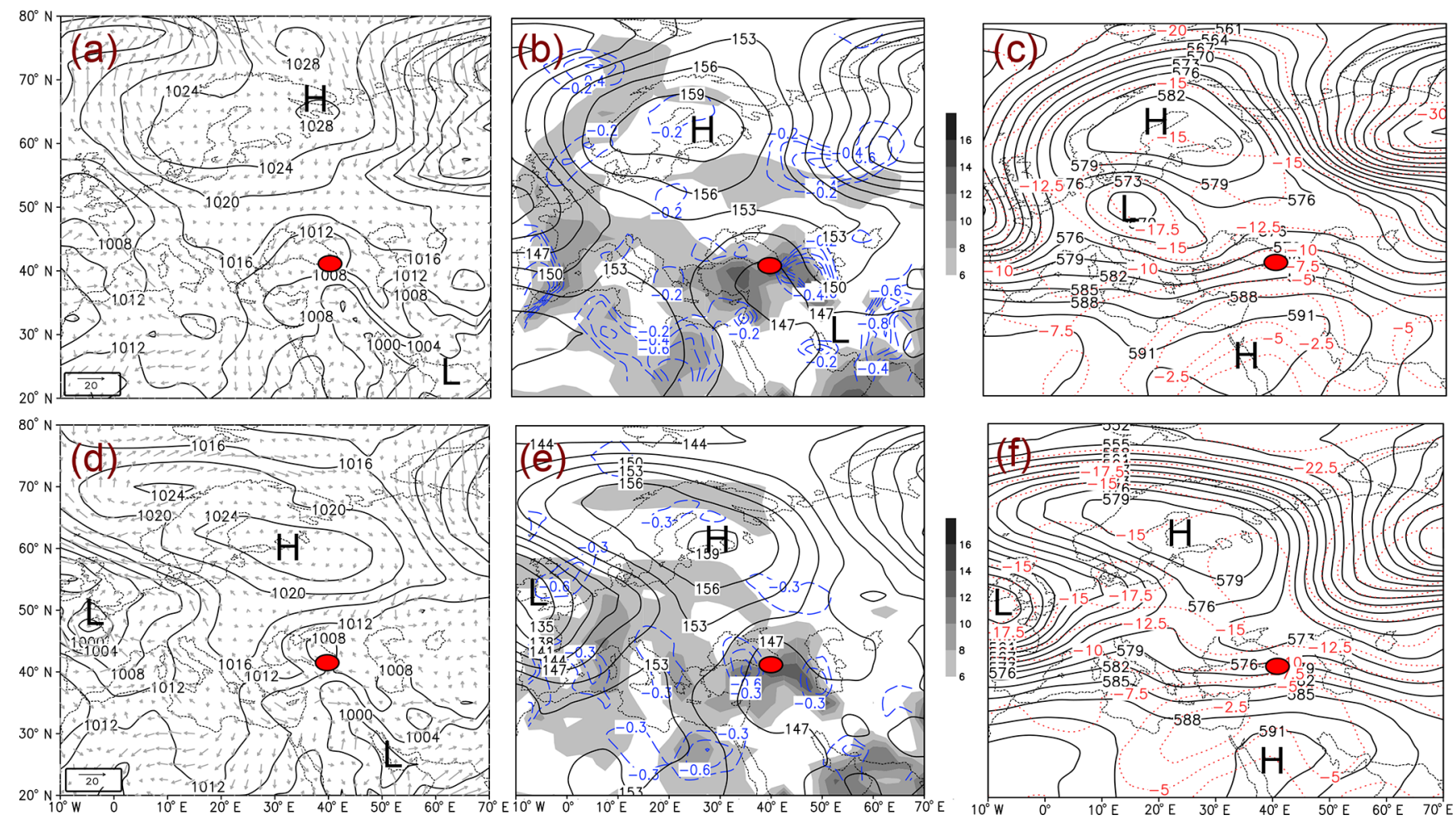

Figure 5. (a) Sea-level pressure chart (lines, units in $\mathrm{hPa}$ ) and surface winds (arrows, units in $\mathrm{m} \mathrm{s}^{-1}$ ). (b) Geopotential height field (units in $\mathrm{dm}$ ), specific humidity contents (shaded in colors, units in $\mathrm{g} \mathrm{kg}^{-1}$ ), and moisture convergence values (dashed lines, removed positive values) of the $850 \mathrm{hPa}$ level. (c) Geopotential height field (units in $\mathrm{dm}$ ), and temperature values (dashed red lines in ${ }^{\circ} \mathrm{C}$ ) of the $500 \mathrm{hPa}$ level. Synoptic charts are from the 23 August 2015, 00:00 UTC. The data of surface, lower and upper levels are derived from NCEP/NCAR reanalysis. Red dot marks the studied region. Panel (d) is the same as (a), (e) is the same as (b), and (f) is the same as (c), but for 24 August 2015, 00:00 UTC.

after they suddenly dropped from 4 to $2 \mathrm{~mm}$ between 01:00 and 05:00 UTC on 24 August. Later, uninterrupted extreme rainstorms hit the north and coasts of the Artvin district. According to the hourly rainfall observations, the highest precipitation amounts were recorded at Hopa over the $8 \mathrm{~h}$ of the flash-flood day (Fig. 4b). The maximum daily precipitation value was observed with $144.3 \mathrm{~mm}$ in $6 \mathrm{~h}$ (starting at 05:00 UTC and ending at 11:00 UTC) in Hopa, and maximum hourly rainfall measured $51.5 \mathrm{~mm}$ at 09:00 UTC. In Arhavi, daily total precipitation was $135.5 \mathrm{~mm}$ and reached a maximum value at 00:00 UTC with $32.4 \mathrm{~mm}$. In Borçka, while daily precipitation amounts were higher $(148.9 \mathrm{~mm})$ than at Hopa and Arhavi, peak values of hourly precipitation intensities were lower. According to the results from these three stations, hourly precipitation reached a maximum value at 09:00 UTC in the low altitudes of the region; this implies that the precipitation was much lower in the upper sectors of the mountainous area.

\subsection{Synoptic overview}

This section summarizes the atmospheric circulation and associated physical mechanisms that were responsible for the flash flood in the region. In order to better evaluate the phe- nomenology of the event, pre-existing synoptic conditions starting from 23 August were investigated. At 00:00 UTC on 23 August, the summer Asian monsoon low extends to the eastern Black Sea (Fig. 5a). During the summer months, in consequence of the excessive surface heating over the arid regions of the Middle East, the monsoon low expands westward and generates the Persian trough (Alpert et al., 2004; Saaroni et al., 2010), which extends to Turkey, forming a thermal low over the eastern Mediterranean (Tyrlis et al., 2015). Besides the surface synoptic conditions, lowlevel moisture convergence, specific humidity content, and geopotential height values of $850 \mathrm{hPa}$ were extracted. It is known that low-level moisture convergence is a good indicator for large-scale precipitation (e.g., Fragoso et al., 2012), and eastern Turkey (and Azerbaijan) has good synoptic precipitation conditions. In the upper levels, interaction between a weak ridge over northern Africa and a trough over the Aegean Sea (because of the upper-level cold low over central Europe) concludes with southwesterly winds over the Artvin district (Fig. 5c).

On 24 August at 00:00 UTC, a high-pressure center (HPC) over northern Russia moved to the south, located around $30^{\circ} \mathrm{E}, 60^{\circ} \mathrm{N}$. While the cyclone remained almost stationary, a new cutoff cyclone occurred over the EBS (Fig. 5d). Thus, 

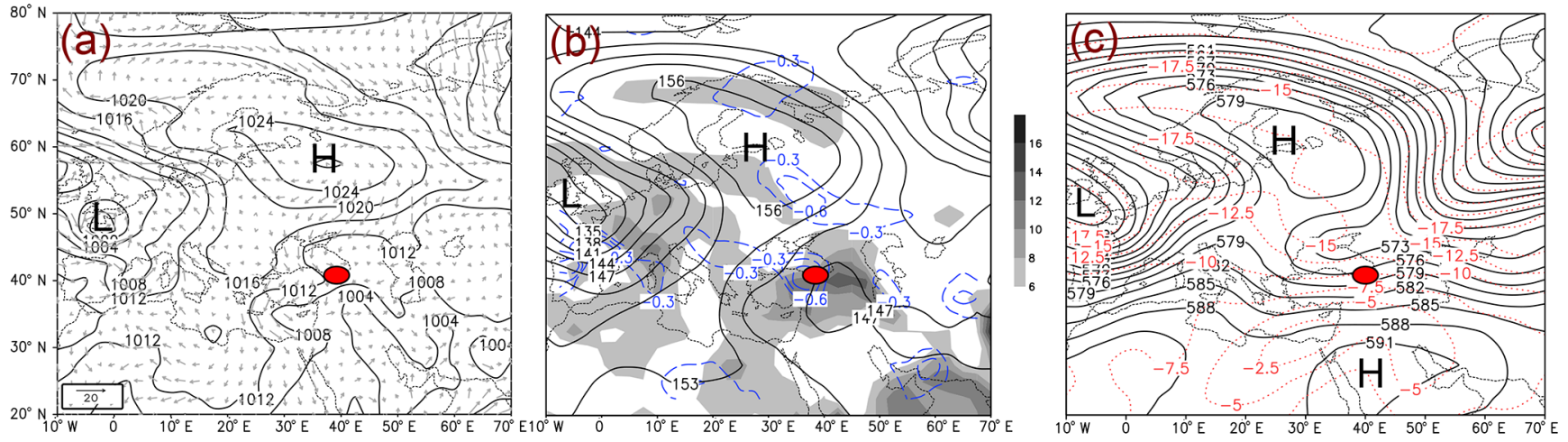

Figure 6. (a) Same as Fig. 5a, (b) same as Fig. 5b, (c) same as Fig. 5c, but for 24 August 2015, 06:00 UTC.

(a)

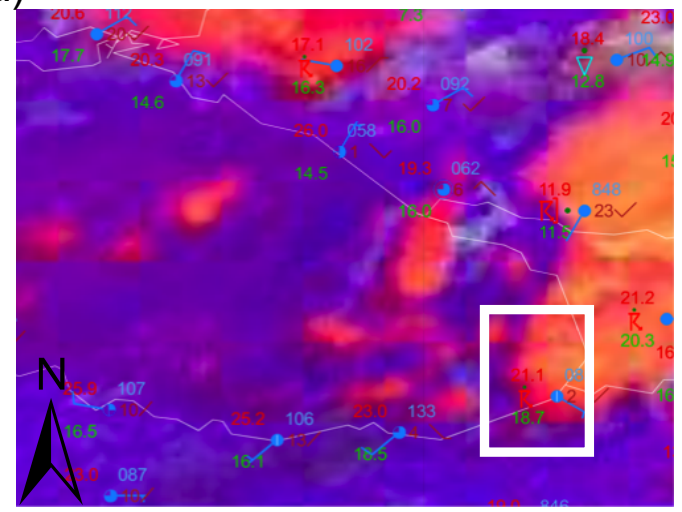

(b)

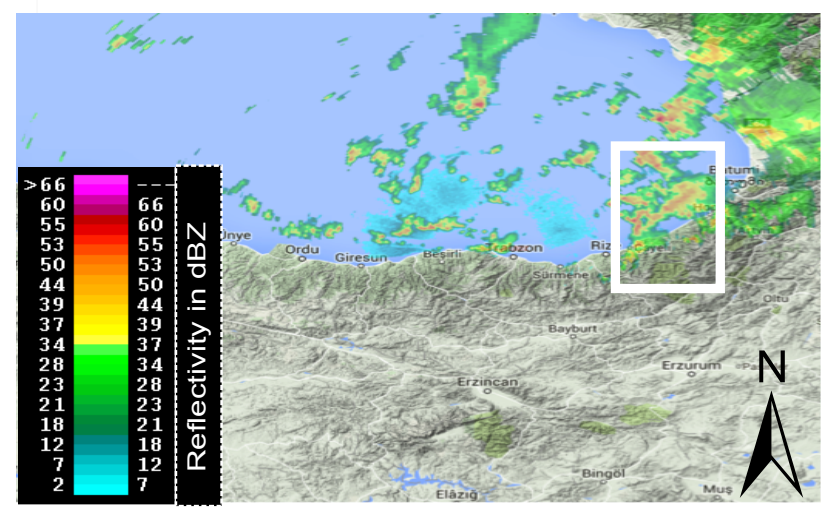

Figure 7. Satellite and radar images on 24 August 2015, 06:00 UTC. (a) Convective storm RGB product from SEVIRE MSG (Meteosat Second Generation) together with SYNOP observations. (b) Radar PPI (Plan Position Indicator) image of the EBS region. Sources: (a) EUMETRAIN (http://www.eumetrain.org/), (b) Turkish State Meteorological Service (www.mgm.gov.tr).

high northeasterly winds brought moisture from the Black Sea to the eastern coasts of Turkey (Fig. 5e). As a result, deep precipitation areas were observed over these regions according to the low-level moisture convergence results. In the upper-level chart $(500 \mathrm{hPa})$, shifting cold core of upper-level high to the south cause the moving of midlatitude low to the west, and thus southwesterly winds turn into the westerly together with a decrease in temperature from -7.5 to $-10^{\circ} \mathrm{C}$ (Fig. 5f).

At the start of the rainstorm (24 August, 06:00 UTC), similar surface and upper-level large-scale circulations appeared and were compared with the midnight synoptic conditions (Fig. 6a and c). Strong moisture convergence zones were detected over the flash-flood region (Fig. 6b). For this reason, thermodynamic analysis was needed to better understand the evaluation of physical mechanisms that developed severe precipitation. Hence, as a consequence of analyzing the nearest radiosonde measurements from Samsun station $\left(41.34^{\circ} \mathrm{N}, 36.25^{\circ} \mathrm{E}\right)$, instability indices such as CAPE (convective available potential energy) and LI (lifted index) showed that there was no strong convective activity before and during the rainstorm (not shown).

In order to follow the distribution convective cells and cloud droplets in a large area, it was necessary to use satellite and radar image data.

\subsection{Satellite and radar images}

Repeated temporal resolution data are an excellent tool for understanding the spatial distribution of the convective cells. Therefore, SEVIRE (Spinning Enhanced Visible and Infrared Imager) MSG (Meteosat Second Generation) outputs were used to examine the atmospheric conditions on 24 August at 06:00 UTC. It is known that "convective storms RGB" product visualizes the particle size features of highlevel cloud tops with good contrast (Kerkmann et al., 2006). Whereas yellowish cloud tops indicate opaque ice clouds with small particles, high-level opaque ice clouds with large particles are shown as reddish. The RGB product in Fig. 7a was produced by assigning the brightness temperature difference (BTD) 6.2-7.3 values as the red component, the BTD 

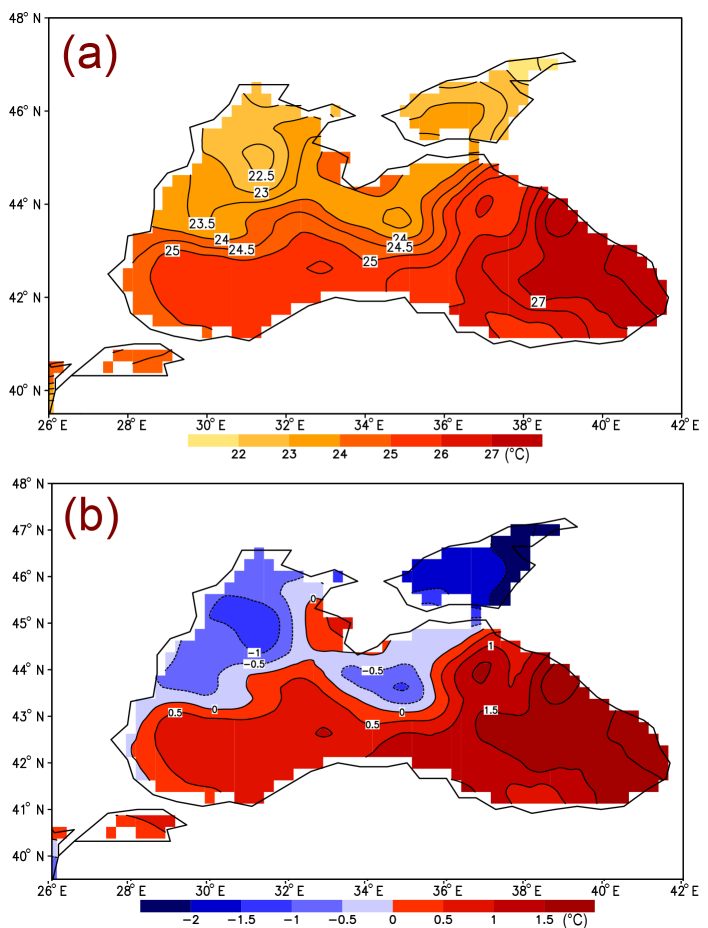

Figure 8. (a) Spatial distribution of the long-term (1960-2014) mean of August sea surface temperatures (SSTs) over the Black Sea. (b) Anomaly values of the 24 August daily mean SSTs when compared with long-term August mean SSTs. The SST reanalysis data are derived from NOAA high-resolution SSTs (from their website at http://www.esrl.noaa.gov/psd).

3.9-10.8 as the green component, 1.6-0.6 as the blue component. In Fig. 7a, numerous convective storms with large ice particles are shown over the EBS. On the other hand, more intense storms were observed over the land areas such as Georgia and this implies the storm intensity. Separately, SYNOP observations indicate that southerly winds over the coast of the EBS stations met with humid northerly flows throughout the seaside area. If the land $\left(21^{\circ} \mathrm{C}\right)$ and sea surface temperatures (SSTs) were sufficiently different, the convective instability and storm severity could have increased with time. As seen in Fig. 7b, high PPI (plan position indicator) reflectivity values from the radar image showed that two cores of the extreme precipitation were over Hopa and Çayeli sub-basins.

\subsection{Sea surface temperature (SST) analysis over the Black Sea}

The influence of SSTs on precipitation over Turkey was investigated in detail by Bozkurt and Sen (2011). They found that increased SSTs led to increased precipitation over the peninsula, especially downwind of the sea. Later, Kömüşçü and Çelik (2013) explained that the warm Aegean SST is one of the significant causes of the development of rainstorms. In (a)

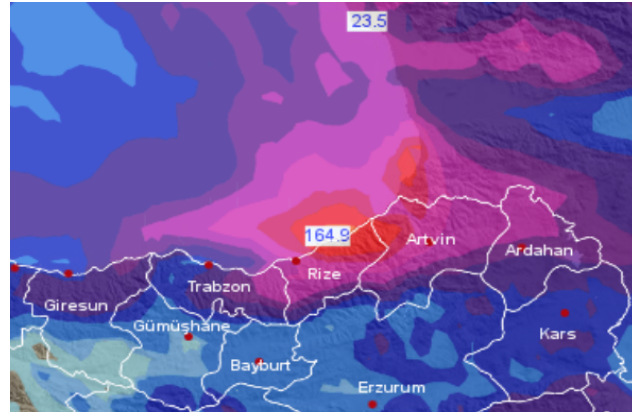

(b)

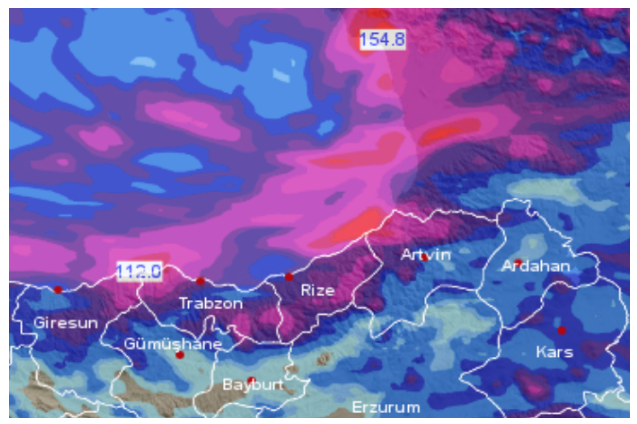

(c)

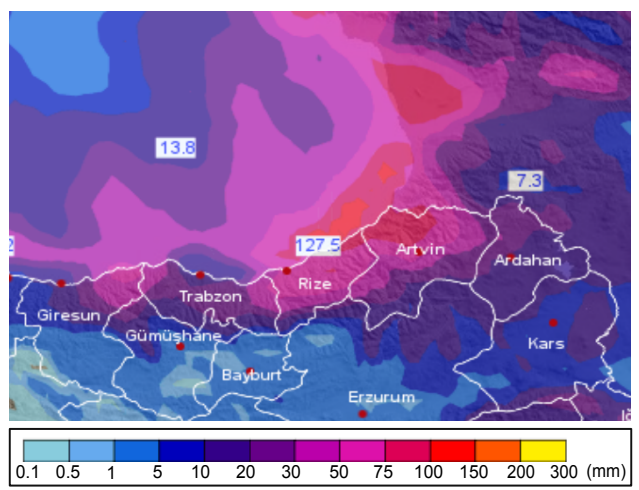

Figure 9. Numerical weather prediction (NWP) precipitation forecasts for the $24 \mathrm{~h}$ daily precipitation totals belonging to the $24 \mathrm{Au}-$ gust 2015 in the EBS region (a) for ECMWF (b) for ALARO and (c) for WRF. Source: Turkish State Meteorological Service (TSMS).

this study, exploring the role of Black Sea surface temperatures on storm development, long-term (1982-2015) means of August SSTs were extracted for the BS using NOAA highresolution SST data (provided by NOAA/OAR/ESRL PSD, Reynolds et al., 2007). As seen in Fig. 8a, cold SSTs of the BS were north of the latitude of $44^{\circ} \mathrm{N}$. The warmest pool of the BS was in the eastern BS, and SSTs exceeded $27^{\circ} \mathrm{C}$ in this month. During the day of the extreme event, spatial distribution of the SSTs indicates negative anomaly values in north of $44^{\circ} \mathrm{N}$ latitudes (Fig. 8b). The EBS region has the highest SST anomalies and $1.5^{\circ} \mathrm{C}$ higher SST variations compared with the August means for the EBS. 


\subsection{Forecasting tools: numerical weather prediction (NWP) models}

According to the ECMWF daily precipitation product, spatial coverage of the maximum daily precipitation values (over $160 \mathrm{~mm}$ ) is shown in the northern Rize and northwestern Artvin cities (Fig. 9a). Compared with the model output (Fig. 4a), station observations were clearly underestimated in northern Rize. On the other hand, model predictions for the Arhavi and Borçka settlements, except Hopa, were good. With regard to the Alaro model results, the highest daily precipitation totals were only well predicted for the Hopa district at $150 \mathrm{~mm}$ (Fig. 9b). Although precipitation forecasts of this limited-area model described Hopa well, the other two flood regions were not well predicted. Optimum spatial coverage of the daily precipitation forecasts is shown in the mesoscale WRF outputs (Fig. 9c). The problem with this model is the underestimated forecasts compared with the observation data. In TSMS, meteorologists merge the outputs of these models (the so-called "poor man ensemble") with their own experience and provide quantitative precipitation forecasts for the alert subregions in predefined time windows. As a consequence of this subjective prediction, TSMS and its regional weather forecast offices issued alert messages related to natural hazards including severe precipitation events. These organizations also carry the responsibility for nowcasting and monitoring rainfall events. According to the main alert on 23 August 2015 at 09:00 UTC prepared by TSMS Weather Forecast Centre, very intense precipitation between 51 and $100 \mathrm{~mm}$ was predicted at the Rize, Artvin, and Trabzon districts within $12 \mathrm{~h}$ of 24 August. The authorities and the public were alerted to the risk of flash-flood, lightning, and landslide events.

\section{Conclusions}

This paper investigated the meteorological role in an extraordinary rain event over Artvin. The flooding event on $24 \mathrm{Au}-$ gust 2015 that hit the Artvin area has been analyzed from a meteorological perspective. A large amount of precipitation fell in an area of a few square kilometers with high intensity in about 6 to $7 \mathrm{~h}$, and NWP models cannot predict such extreme events well. Although alert messages were prepared by TSMS on 23 August at 09:00 UTC, 11 people died and infrastructures, buildings, private property, and public goods were damaged as a result of the flash flood.

According to the synoptic conditions, when the summer monsoon frontal system extended to eastern Anatolia, its activity was enhanced. On the other hand, because of the depressive effect of the Siberian high from the north, a cutoff low occurred over the eastern Black Sea. As a result, a slow-moving quasistationary cutoff low over the Black Sea increased the SSTs and more moisture was transported from the sea to the atmosphere. Thus, strong moisture convergence at low levels $(850 \mathrm{hPa})$ was observed over Artvin city. Moreover, warm humid northerly airs from the Black Sea and relatively cool southerly flows $\left(21^{\circ} \mathrm{C}\right)$ over the land areas increased the instability conditions and redevelopment of the convective cells over the same region enhanced the rainfall intensity.

The synoptic and atmospheric descriptions give better knowledge of the mesoscale convective systems and the mechanisms driving torrential rains in the EBS. It is hoped that more detailed studies will be performed on synoptic development leading to extreme summer precipitation events in EBS.

Data availability. The following data sets are publicly available. Synoptic charts of the extreme event are available at https://www. esrl.noaa.gov/psd/data/gridded/data.ncep.reanalysis.html. Sea surface temperature data are available at https://www.esrl.noaa.gov/ $\mathrm{psd} / \mathrm{data} / \mathrm{gridded} /$ data.noaa.oisst.v2.highres.html. The satellite data used for the case study are available at http://www.eumetrain.org/. Any other data of interest can be requested by email to the corresponding author.

Competing interests. The author declares that he has no conflict of interest.

Edited by: Heidi Kreibich

Reviewed by: three anonymous referees

\section{References}

Alpert, P., Osetinsky, I., Ziv, B., and Shafir, H.: A new seasons definition based on classified daily synoptic systems: an example for the eastern Mediterranean, Int. J. Climatol., 24, 1013-1021, 2004.

Aronica, G. T., Brigandi, G., Marletta, C., and Manfre, B.: Hydrological and hydraulic analysis of the flash flood event on 25 October 2007 in North-Eastern part of Sicily, Italy, in: Proceedings of Floodrisk 2008, 30 September-2 October 2008, Oxford, UK, 2008.

Biyik, G., Unal, Y. S., and Onol, B.: Assessment of Precipitation Forecast Accuracy over Eastern Black Sea Region using WRFARW, European Geosciences Union General Assembly, Vienna, 2 May 2010-7 May 2010, 2010.

Borga, M., Boscolo, P., Zanon, F., and Sangati, M.: Hydrometeorological Analysis of the 29 August 2003 Flash Flood in the Eastern Italian Alps, J. Hydrometeorol., 8, 1049-1067, 2007.

Bozkurt, D. and Sen, O. L.: Precipitation in the Anatolian Peninsula: sensitivity to increased SSTs in the surrounding seas, Clim. Dynam., 36, 711-726, 2011.

Delrieu, G., Nicol, J., Yates, E., Kirstetter, P. E., Creutin, J. D., Anquetin, S., Obled, C. H., Saulnier, G. M., Ducrocq, V., Gaume, E., Payrastre, O., Andrieu, H., Ayral, P. A., Bouvier, C., Neppel, L., Livet, M., Lang, M., Parent du-Châtelet, J., Walpersdorf, A., and Wobrock, W.: The catastrophic flash-flood event of 8-9 September 2002 in the Gard region, France. A first case study for the 
Ceìvennes-Vivarais mediterranean hydrometeorological observatory, J. Hydrometeorol., 6, 34-52, 2005.

Eris, E. and Agiralioglu, N.: Homogeneity and trend analysis of hydrometeorological data of the Eastern Black Sea region, Turkey, Journal of Water Resource and Protection, 4, 99-105, 2012.

Fragoso, M., Trigo, R. M., Pinto, J. G., Lopes, S., Lopes, A., Ulbrich, S., and Magro, C.: The 20 February 2010 Madeira flash-floods: synoptic analysis and extreme rainfall assessment, Nat. Hazards Earth Syst. Sci., 12, 715-730, https://doi.org/10.5194/nhess-12-715-2012, 2012.

Gaume, E., Bain, V., and Bernardara, P.: Primary Flash flood Data, Work Package 1 Report for HYDRATE, EC Project No. GOCECT-2004-505420, 2008.

Gerard, L.: An integrated package for subgrid convection, clouds and precipitation compatible with the meso-gamma scales, Q. J. Roy. Meteor. Soc., 133, 711-730, 2007.

Gerard, L. and Geleyn, J. F.: Evolution of a subgrid deep convection parameterization in a limited area model with increasing resolution, Q. J. Roy. Meteor. Soc., 131, 2293-2312, 2005.

Gerard, L., Piriou, J. M., Brozkova, R., Geleyn, J. F., and Banciu, D.: Cloud and precipitation parameterization in a mesogamma-scale operational weather prediction model, Mon. Weather Rev., 137, 3960-3977, 2009.

Huet, P., Martin, X., Prime, J- L., Foin, P., Laurain, C. I., and Cannard, Ph.: Retour d'Expériences des Crues de Septembre 2002 dans les Départements du Gard, de l'Hérault, du Vaucluse, des Bouches du Rhône, de l'Arde 'che et de la Drôme, Inspection générale de l'Environnement, Paris, France, 124 pp., 2003.

Janjic, Z. I.: A nonhydrostatic model based on a new approach, Meteorol. Atmos. Phys., 82, 271-285, 2003.

Kerkmann, J., Lutz, H. J., König, M., Prieto, J., Pylkko, P., Roesli, H. P., Rosenfeld, D., and Zwatz-Meise, G.: 20060 MSG Channels, Interpretation Guide, Weather, surface Conditions and Atmospheric Constituents, available at: http://oiswww.eumetsat. org/WEBOPS/msg_interpretation/index.html (last access: July 2017), 2006.

Kotroni, V., Lagouvardos, E., Defer, S., Dietrich, F., Porcu, C., Medaglia, C. M., and Demirtas, M.: The Antalya 5 December 2002 storm: observations and model analysis, J. Appl. Meteorol. Clim., 45, 576-590, 2006.

Kömüşçü, A. Ü. and Çelik, S.: Analysis of the Marmara flood in Turkey, 7-10 September 2009: an assessment from hydrometeorological perspective, Nat. Hazards, 66, 781-808, 2013.
Kömüşçü, A. Ü., Erkan, A., and Çelik, S.: Analysis of meteorological and terrain features leading to the İzmir Flash Flood, 3-4 November 1995, Nat. Hazards, 18, 1-25, 1998.

Llasat, M. C., De Batlle, J., Rigo, T., and Barriendos, M.: Las inundaciones del 10 de Junio del 2000 en Catalana, Revista Ingenieria del Agua, 8, 53-66, 2001.

Milelli, M., Llasat, M. C., and Ducrocq, V.: The cases of June 2000, November 2002 and September 2002 as examples of Mediterranean floods, Nat. Hazards Earth Syst. Sci., 6, 271-284, https://doi.org/10.5194/nhess-6-271-2006, 2006.

Rebora, N., Molini, L., Casella, E., Comellas, A., Fiori, E., Pignone, F., Siccardi, F., Silvestro, F., Tanelli, S., and Parodi, A. Extreme rainfall in the Mediterranean: what can we learn from observations?, J. Hydrometeorol., 14, 906-922, 2013.

Reynolds, R. W., Smith, T. M., Liu, C., Chelton, D. B., Casey, K. S., and Schlax, M. G.: Daily high-resolution-blended analyses for sea surface temperature, J. Climate, 20, 5473-5496, 2007.

Saaroni, H., Ziv, B., Osetinsky, I., and Alpert, P.: Factors governing the interannual variation and the long-term trend of the $850 \mathrm{hPa}$ temperature over Israel, Q. J. Roy. Meteor. Soc., 136, 305-318, 2010.

Silvestro, F., Gabellani, S., Giannoni, F., Parodi, A., Rebora, N., Rudari, R., and Siccardi, F.: A hydrological analysis of the 4 November 2011 event in Genoa, Nat. Hazards Earth Syst. Sci., 12, 2743-2752, https://doi.org/10.5194/nhess-122743-2012, 2012.

Tyrlis, E., Tymvios, F. S., Giannakopoulos, C., and Lelieveld, J.: The role of blocking in the summer 2014 collapse of Etesians over the eastern Mediterranean, J. Geophys. Res.-Atmos., 120, 6777-6792, 2015

Unal, Y. S., Deniz, A., Toros, H., and Incecik, S.: Temporal and spatial patterns of precipitation variability for annual, wet, and dry seasons in Turkey, Int. J. Climatol., 32, 392-405, 2012.

Üçüncü, O., Önsoy, H., and Yüksek, Ö.: A study on the environmental effects of 20 June 1990 flood in Trabzon and its neighborhood, Turkey, 2nd International Conference on River Flood Hydraulics, York, England, 22-25 March 1994, 1994.

Yüksek, Ö., Kankal, M., and Üçüncü, O.: Assessment of big floods in the Eastern Black Sea Basin of Turkey, Environ. Monit. Assess., 185, 797-814, 2013. 